\title{
Behavior of coffee seeds to desiccation tolerance and storage ${ }^{1}$
}

\author{
Luciana Aparecida de Souza Abreu ${ }^{2 *}$, Adriano Delly Veiga ${ }^{3}$, \\ Édila Vilela de Resende Von Pinho², Fiorita Faria Monteiro ${ }^{4}$, \\ Sttela Dellyzette Veiga Franco da Rosa ${ }^{5}$
}

\begin{abstract}
The technology developed by breeding programs is applied to coffee seeds; however, after processing and drying, they lose viability within a short period of time, thus making storage unsuitable. The objective of this research was to evaluate the quality of coffee seeds submitted to different drying methods and moisture contents during storage. The coffee seeds were submitted to conventional drying (slow shade drying) and fast drying in a static drier until they reached a moisture content of 40, 20, 12 and 5\%. After this process, the seeds were stored in a cold chamber for 12 months, and seed quality was evaluated before and during storage by the germination test, electrophoretic patterns of heat resistant proteins, and the activity of isoenzyme systems. Conventional drying (slow shade drying) at $20 \%$ of moisture content maintains coffee seed quality until 12 months of storage.
\end{abstract}

Index terms: Coffea arabica L., longevity, desiccation tolerance, oxidative stress.

\section{Comportamento de sementes de cafeeiro quanto à tolerância à dessecação e ao armazenamento}

RESUMO - A semente do cafeeiro agrega toda a tecnologia desenvolvida pelos programas de melhoramento, porém, após o processamento e secagem, perdem a viabilidade em curto período de tempo, dificultando o seu armazenamento. Assim, objetivouse com a pesquisa avaliar a qualidade de sementes de cafeeiro submetidas a diferentes métodos de secagem e ao armazenamento. Sementes de cafeeiro foram secadas até atingirem os teores de 40,20, 12 e 5\% de água por meio de dois métodos de secagem: lenta à sombra e rápida em secador mecânico. Após este processo, as sementes foram armazenadas em câmara fria por doze meses, sendo a qualidade, avaliada antes e ao final do armazenamento pelo teste de germinação, padrão eletroforético de proteínas resistentes ao calor e atividade das enzimas catalase, peroxidase, superóxido dismutase. A secagem lenta a sombra até $20 \%$ de teor de água propicia a conservação da qualidade em sementes de cafeeiro por até doze meses de armazenamento.

Termos para indexação: Coffea arabica L., longevidade, tolerância à dessecação, estresse oxidativo.

\section{Introduction}

Studies that shed light on the complex physiology of desiccation and deterioration of coffee seeds during storage are extremely important because coffee crops are economically and socially relevant for Brazil. These studies can be used as the theoretical basis for selecting adequate post-harvest processes which will benefit coffee seed producers.

The technology developed by breeding programs is fully applied to coffee seeds. However, after processing and drying, the seeds lose viability within a short period of time, and they

${ }^{1}$ Submitted on 07/21/2014. Accepted for publication on 09/09/2014. ${ }^{2}$ Departamento de Agricultura, UFLA, Caixa Postal, 3037, 37200 - Lavras, MG, Brasil.

${ }^{3}$ Embrapa Café, UFLA, Caixa Postal 3037, 37200-000,Lavras- MG, Brasil. ${ }^{4}$ Universidade Federal de Lavras, Caixa Postal, 3037, 37200-000, LavrasMG, Brasil. do not maintain germination quality at satisfactory levels for longer than six months after harvest (Araújo et al., 2008).

Seed longevity is associated with desiccation tolerance of seeds. Coffee seeds are classified as having an intermediate behavior towards drying and storage (Ellis et al., 1991), based on the fact that they tolerate storage for up to twelve months at $15^{\circ} \mathrm{C}$ after desiccation to approximately $10 \%$ water content. However, existing studies on the performance of coffee seeds after drying and storage are contradictory and inconclusive (Santos et al., 2013). Research conducted with the aim of determining techniques to extend the shelf life of coffee seeds have shown

\footnotetext{
${ }^{5}$ Embrapa Café, Departamento de Agricultura, UFLA, Caixa Postal 3037 37200-000 - Lavras, MG, Brasil.

*Corresponding author<luapsouza2003@yahoo.com.br>
} 
conflicting results, especially for water content (Gentil, 2001).

Increased desiccation tolerance of coffee seeds is observed when slow drying is performed, probably due to the time allowed for induction and protection mechanisms. Thus, damage to membrane systems may occur during fast drying, preventing recovery processes. Thus, more time may be required for repairs during germination (Santos et al., 2013).

Several studies have shown that slow drying provides top quality coffee seeds (Veiga et al., 2007, Vieira et al., 2007), which makes it recommended and frequently used for seeds of this species. While slow drying is used as a method to simulate desiccation as it occurs in maturation, fast drying is the most appropriate way to evaluate the extent of desiccation tolerance at a particular stage of development. Vieira et al. (2007) found that slow drying results in seeds with better physiological quality, while Rosa et al. (2005) pointed out that slow drying resulted in poorer-quality seeds. Thus, the method of drying can greatly influence desiccation tolerance of coffee seeds.

Therefore, this study aimed to investigate the quality of coffee seeds subjected to different drying methods and storage.

\section{Material and Methods}

The research was conducted in the Central Seed Laboratory of the Federal University of Lavras (UFLA). Seeds of the specie Coffea arabica L., cultivar Catuaí Amarelo IAC 62, were used. They were collected in cropping fields of Procafé Foundation, in the city of Varginha, state of Minas Gerais.

The coffee fruits were picked selectively at the red ripe stage and pulped, and mucilage was removed mechanically before drying. Average seed water content was 52\% at that point (control not subjected to drying). Ten kilograms of seeds were dried until they reached water contents of 40,20, 12 and 5\% through two drying methods: slow shade drying and fast drying in a small static dryer at $35{ }^{\circ} \mathrm{C}$ and air flow of about $20 \mathrm{~m}^{3} \cdot \mathrm{min}^{-1} \cdot \mathrm{t}^{-1}$. Seed water content was determined by the oven method at $105^{\circ} \mathrm{C}$ for 24 hours, using two replicates for each treatment (Brasil, 2009).

During the drying processes, samples consisted of $1 \mathrm{~kg}$ of seeds of each treatment with different water contents. The seeds were stored in plastic bags at $10{ }^{\circ} \mathrm{C}$ and with relative humidity of $50 \%$. Before storage and at every four months of storage, the quality of coffee seeds was evaluated for physiological aspects by the following tests:

Germination test - performed with four replicates of 50 seeds per treatment. Paper towel rolls were used as substrate, moistened with a quantity of water equal to 2.5 times the dry weight of the substrate and maintained in germinators at $30^{\circ} \mathrm{C}$. Counts were made at fifteen and thirty days after sowing (Brasil, 2009), and the results were expressed as percentage of normal seedlings. Root protrusion - conducted at fifteen days after the beginning of the germination test, by counting the seeds that had the taproot and at least two lateral roots. The results were expressed in percentage terms.

Isoenzyme analysis - samples of 100 grams of seeds were taken from the treatments before and after storage for electrophoretic analysis of enzymes. The samples were ground in a mortar on ice in the presence of PVP and liquid nitrogen and they were subsequently stored at $-86^{\circ} \mathrm{C}$. For enzyme extraction, Tris $\mathrm{HCl} 0.2 \mathrm{M} \mathrm{pH} 8.0+(0.1 \% \beta$-mercaptoethanol $)$ was used at a ratio of $250 \mu \mathrm{L}$ per $100 \mathrm{mg}$ of seeds. The material was homogenized by vortexing and kept overnight in a refrigerator, followed by centrifugation at $14,000 \mathrm{xg}$ for 30 minutes at $4{ }^{\circ} \mathrm{C}$. The electrophoretic runs were performed on polyacrylamide gels at 7.5\% (separating gel) and $4.5 \%$ (concentrating gel). The gel/electrode system used was Tris-glycine $\mathrm{pH}$ 8.9. $50 \mu \mathrm{L}$ of the supernatant from the sample was applied to the gels and the run was performed at $150 \mathrm{~V}$ for 4 hours. After the run, the gels were stained for enzymes catalase, esterase, peroxidase, and superoxide dismutase according to Alfenas (2006) and then analyzed visually.

For extraction of heat resistant proteins, (50 mM Tris$\mathrm{HCl} \mathrm{pH} 7,5 ; 500 \mathrm{mM} \mathrm{NaCl} ; 5 \mathrm{mM} \mathrm{MgCl} ; 1 \mathrm{mM}$ PMSF) were added to the buffer solution at a ratio of 1:10 (material weight: extraction buffer volume) and transferred to 1,500 $\mu \mathrm{L}$ microcentrifuge tubes. The homogenate was centrifuged for 45 minutes at $4{ }^{\circ} \mathrm{C}$ at $16,000 \mathrm{xg}$, and the supernatant was removed and incubated in a water bath at $85^{\circ} \mathrm{C}$ for 15 minutes and then centrifuged again for 30 minutes. The supernatant was poured into microtubes, and the pellet was discarded. Before application to the gel, sample tubes containing $70 \mu \mathrm{L}$ extract + $40 \mu \mathrm{L}$ of sample buffer solution $(2.5 \mathrm{~mL}$ glycerol, $0.46 \mathrm{~g} \mathrm{SDS}$, $20 \mathrm{mg}$ of bromophenol blue, and the volume completed to 20 $\mathrm{mL}$ with extraction buffer Tris $\mathrm{pH}$ 7.5) were placed in a bath of boiling water for 5 minutes. $50 \mu \mathrm{L}$ of this solution were applied to SDS-PAGE polyacrylamide gel at $12.5 \%$ in the separating gel and at $6 \%$ in the concentrating gel. Electrophoresis was performed at $150 \mathrm{~V}$ and the gel was stained with Coomassie Blue at $0.05 \%$, according to Alfenas (2006), for 12 hours and bleached in a solution of $10 \%$ acetic acid.

Experimental design - completely randomized with four replications in a $(2 \times 4 \times 4)+1$ factorial design, which corresponded to two drying methods (slow and fast), four times (0, 4, 8 and 12 months) and four water contents after drying (40, 20, 12, and $5 \%$ ), plus the control ( $52 \%$ without drying). The analysis of data from the factorial scheme was performed using the statistical program SISVAR ${ }^{\circledR}$ (Ferreira, 2011), and regression analysis was performed for quantitative variation of storage time. The control (52\%), within each period of storage, was compared with 
the treatments of the factorial by Dunnett's test using the GLM procedure of the software $\mathrm{SAS}^{\circledR}$ version 9.0.

\section{Results and Discussion}

By analyzing the germination of coffee seeds, all sources of variation were significant in the analysis of variance. Shadedried seeds had higher values compared to artificial drying along the storage period evaluated (Figure 1). In the study of Veiga et al. (2007) on seeds harvested at the red ripe stage, there was better physiological quality when shade drying was used for all storage times evaluated. Thus, considering all water contents, only non stored, dried seeds (time zero) and shade-dried seeds dried with four months of storage had germination values above the marketable pattern, which is $70 \%$ (Carvalho et al., 2008).

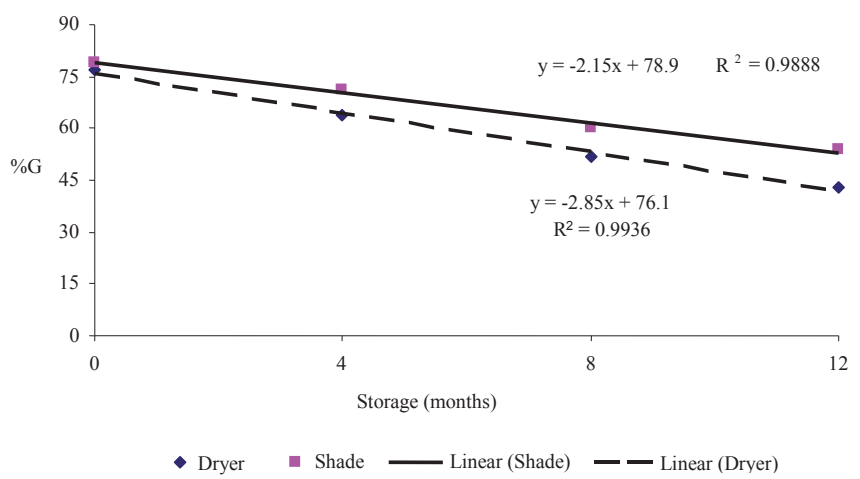

Figure 1. Estimated germination percentage values of coffee seeds subjected to slow drying (shade) and fast drying (dryer), stored for twelve months.

The significant triple interaction among factors method of drying, water content achieved after drying and storage time, showed that the best results for the twelve months were provided by shade drying to a water content of $20 \%$ (Figure 2). In such conditions, high quality seeds can be obtained throughout the storage period evaluated.

Figure 2 shows the drying methods separately for better visualization of germination estimates during storage. When fast drying was used, germination percentage was maintained up to eight months of storage, but only when drying was performed to $20 \%$ seed moisture. Araújo et al. (2008) found that coffee seeds are preserved better when stored at $18.5 \%$ moisture at a low temperature $\left(7{ }^{\circ} \mathrm{C}\right)$ environment while maintaining their germinative ability for up to nine months.

For most tested treatments, there was a reduction in seed quality during storage, especially for seeds dried to $40 \%$ moisture. Seed drying to $5 \%$ water content was drastic to physiological quality, regardless of drying method. Brandão Jr. et al. (2002), who evaluated desiccation tolerance of coffee seeds harvested at different stages of maturation, observed a higher level of desiccation tolerance in coffee seeds with increased development, and seeds dried to $15 \%$ moisture content maintained their physiological quality over nine months of storage. In contrast, non-dried seeds with $50 \%$ moisture content showed a linear decrease of germination during storage.
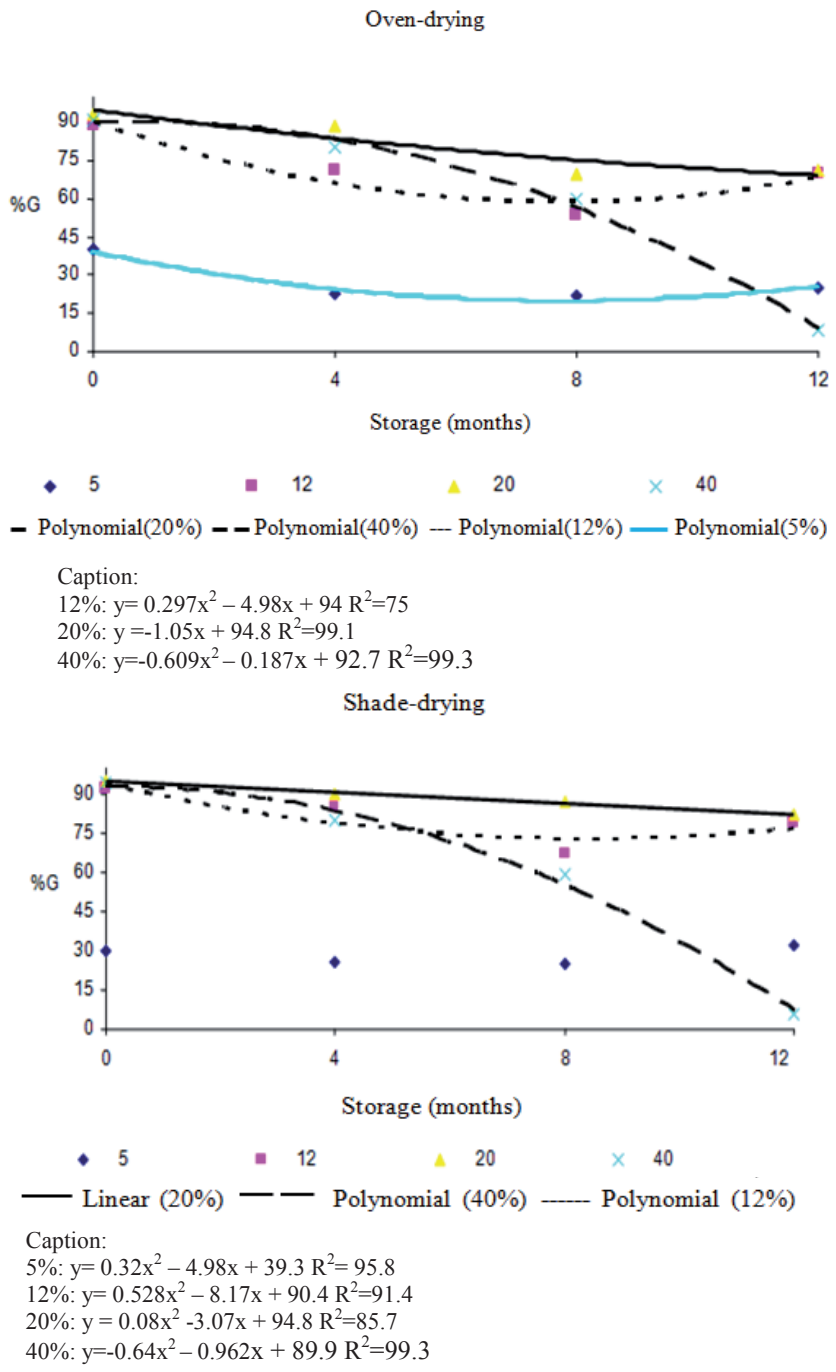

Figure 2. Estimated germination percentage values of coffee seeds subjected to slow drying (shade) and fast drying (dryer) to different water contents and stored for twelve months.

Similar results were found for root protrusion (Figure 3). The triple interaction between factors was significant, and indicated better results with shade drying up to water contents of $20 \%$ and $12 \%$ throughout the storage period. The results also highlighted the reduction of seed vigor 
during storage, especially when the seeds were subjected to water loss by $40 \%$ in both methods of drying, and the dried seeds, by $5 \%$ in the static dryer. When slow drying was used to water content of $5 \%$, seed vigor was maintained during storage. According to Brandão Jr. et al. (2002), the reduction of vigor in seeds subjected to artificial drying causes intense changes such as crystal formation and disappearance of the vacuole and endomembranes, as shown in ultrastructural analyses.

By Dunnett's test, comparisons were made for germination and root protrusion between control (non dried seeds) and each treatment, within each storage time (Table 1).
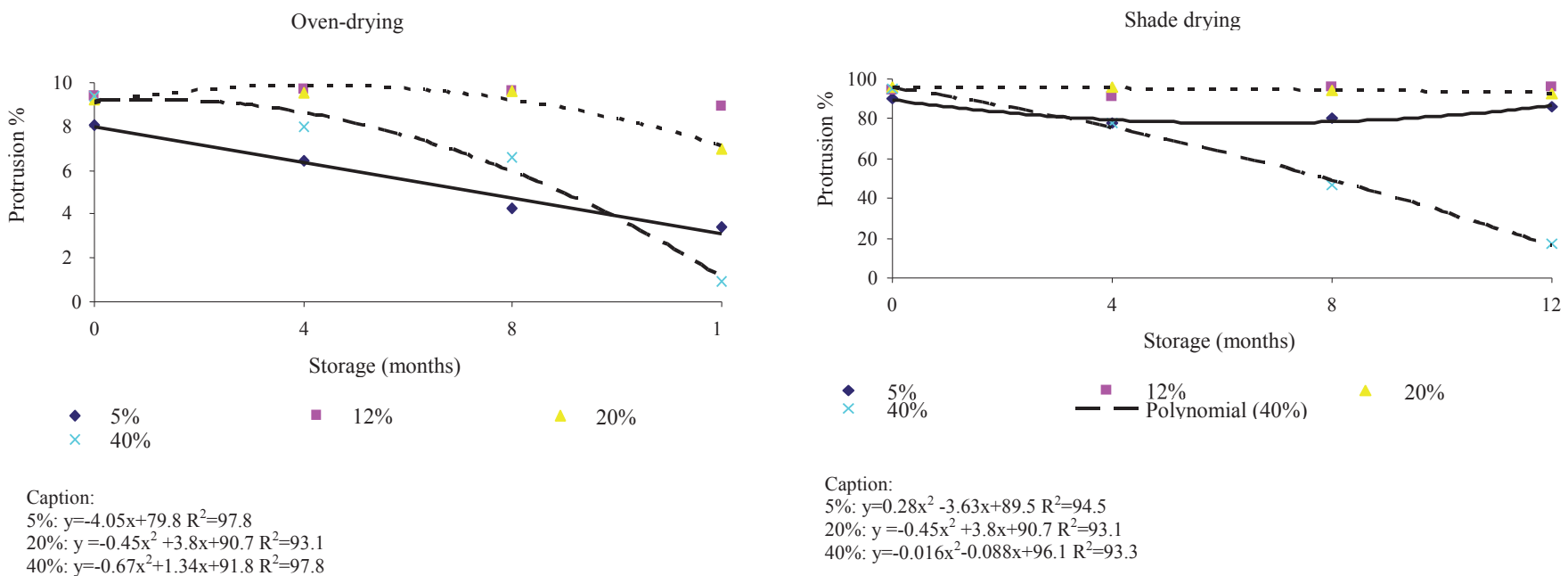

Figure 3. Estimated root protrusion values of coffee seeds subjected to slow drying (shade) and fast drying (dryer), stored for twelve months.

Table 1. Comparison of germination and root protrusion (\%) values of the control with coffee seeds subjected to slow drying (shade) and fast drying (dryer), stored for twelve months.

\begin{tabular}{|c|c|c|c|c|c|c|c|c|}
\hline \multirow{3}{*}{ Treatment } & \multicolumn{8}{|c|}{ Time (months) } \\
\hline & \multicolumn{2}{|c|}{0} & \multicolumn{2}{|c|}{4} & \multicolumn{2}{|c|}{8} & \multicolumn{2}{|c|}{12} \\
\hline & G & RP & G & $\mathrm{RP}$ & G & $\mathrm{RP}$ & G & $\mathrm{RP}$ \\
\hline $5 \%$ oven & $40^{*}$ & $81^{*}$ & $16^{*}$ & $63^{\mathrm{ns}}$ & $22^{* *}$ & $44^{* *}$ & $24^{* *}$ & $35^{* *}$ \\
\hline $5 \%$ shade & $31^{*}$ & $91^{\text {ns }}$ & $26^{*}$ & $78^{\mathrm{ns}}$ & $25^{* *}$ & $81^{* *}$ & $32^{* *}$ & $86^{* *}$ \\
\hline $12 \%$ oven & $87^{\mathrm{ns}}$ & $93^{\mathrm{ns}}$ & $75^{* *}$ & $97^{* *}$ & $54^{* *}$ & $94^{* *}$ & $71^{* *}$ & $85^{* *}$ \\
\hline $12 \%$ shade & $92^{\mathrm{ns}}$ & $95^{\mathrm{ns}}$ & $87^{* *}$ & $91^{* *}$ & $67^{* *}$ & $97^{* *}$ & $84^{* *}$ & $94^{* *}$ \\
\hline $20 \%$ oven & $93^{\mathrm{ns}}$ & $92^{\text {ns }}$ & $90^{* *}$ & $95^{* *}$ & $71^{* *}$ & $96^{* *}$ & $72^{* *}$ & $36^{* *}$ \\
\hline $20 \%$ shade & $96^{\mathrm{ns}}$ & $96^{\mathrm{ns}}$ & $89^{* *}$ & $96^{* *}$ & $88^{* *}$ & $95^{* *}$ & $85^{* *}$ & $93^{* *}$ \\
\hline $40 \%$ oven & $91^{\mathrm{ns}}$ & $96^{\mathrm{ns}}$ & $80^{* *}$ & $90^{* *}$ & $62^{* *}$ & $67^{* *}$ & $7^{\mathrm{ns}}$ & $8^{\mathrm{ns}}$ \\
\hline $40 \%$ shade & $93^{\mathrm{ns}}$ & $95^{\mathrm{ns}}$ & $85^{* *}$ & $88^{* *}$ & $61^{* *}$ & $67^{* *}$ & $6^{\mathrm{ns}}$ & $0^{\mathrm{ns}}$ \\
\hline Control $(52 \%)$ & 92 & 97 & 59 & 64 & 0 & 0 & 0 & 0 \\
\hline
\end{tabular}

**Significant and higher than the control by Dunnett's test at 5\% probability;

*Significant and lower than the control by Dunnett's test at $5 \%$ probability;

${ }^{\mathrm{n} s}$ Not significant by Dunnett's test at $5 \%$ probability.

For germination, a high value was observed before storage for the control; it was significantly different only from the treatments where drying reached up to $5 \%$. For the second storage time, the control had considerable reduction. It was different from both higher values, observed for treatments where drying was performed to 40, 20 and $12 \%$, and for lower values, observed when drying was performed to $5 \%$.
For the subsequent months, significant differences were found for the treatments compared to the control because there was no seed germination in this treatment, except for the seeds dried to $40 \%$ after 12 months of storage. For high water contents, close to $52 \%$ without use of drying, the seeds should not be stored for more than four months. Veiga et al. (2007) found that after eight months of storage, the highest germination value 
was observed in seeds harvested at the yellowish-green stage and shade-dried, while the smallest was found in non dried seeds and seeds dried in the dryer.

For root protrusion, a significant difference before storage was observed only for seeds dried to $5 \%$ moisture in the dryer. After four months of storage, there was no root protrusion of seeds; the control had a considerable reduction in the amount of protrusion, and it was significantly equal to seeds dried to $5 \%$ moisture. In the eighth month of storage, there was no root protrusion in seeds of the control with $52 \%$ moisture, in contrast with all the treatments. This was also observed at twelve months, except for the seeds that were dried to $40 \%$ moisture, which were similar to the control after this period.

Isoenzyme analysis complements the evaluation of physiological seed quality. It is a rapid, sensitive and specific method for this purpose; it detects enzymes associated with seed metabolism, germination, mechanisms of seed protection during drying and storage and also enzymes linked to the deteriorating process. For this study, isoenzyme analyses were performed using only the treatments obtained before and after storage.

The reduction in the activity of free radical scavenger enzymes such as catalase is related to the loss of seed viability (Berjak, 2006), a fact confirmed in seeds dried to $5 \%$, regardless of drying methods (Figure 4). For seeds with low water content dried artificially, this reduction was enhanced after twelve months of storage. For Berjak (2006), damage to membranes by desiccation can be caused by oxidation, which promotes phospholipid esterification or lipid peroxidation. This enzyme is involved in the removal of hydrogen peroxide $\left(\mathrm{H}_{2} \mathrm{O}_{2}\right)$ from cells, and its increased activity may be associated with the decrease in mechanisms that prevent oxidative damage (Bailly et al., 2002).

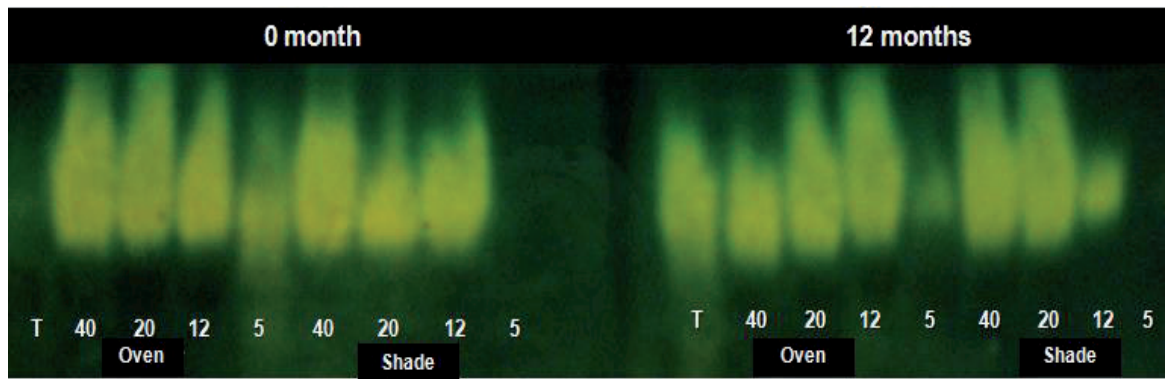

Figure 4. Enzymatic profiles of catalase (CAT) in seeds of Coffea arabica L., depending on drying methods, water content (\%) and time of storage.

There is also an increase in the intensity of bands in the control after storage. This fact is related to increased activity of the enzyme in combating free radicals and antioxidative response under stress (Dussert et al., 2006). The results confirm that moister seeds substantially lose quality during storage, which can be seen in the results of the germination and vigor tests. Lower activity of catalase was observed in the seeds that were not dried, a finding similar to the one by Santos et al. (2014) in coffee seeds, which suggests that the loss of seed viability during the drying process is followed by an increase in the levels of reactive oxygen species (ROS) because of the physiological stress suffered. According to Takahashi et al. (2007), seeds have mechanisms to prevent the formation of ROS. They stated that the action of enzymes such as catalase removes hydrogen peroxide, a highly toxic compound to the seeds.

The expression of the esterase enzyme (Figure 5) has greater activity in seeds dried in a dryer before and after the storage period, especially coffee seeds that contain high water contents, which can be characterized as deteriorating seeds. Nakada et al. (2010) reported that this enzyme is very indicative of seed deterioration. However, for seeds from the treatment without drying (control), no bands were observed, especially at the end of storage. Brandão Júnior et al. (2002) did not identify bands of this enzyme in non dried coffee seeds (control), either.

Desiccation tolerance of seeds is achieved and maintained by means of several mechanisms, including the induction of heat-resistant proteins. The analysis of the electrophoretic profile of heat resistant proteins extracted from coffee seeds (Figure 6) shows a pattern of more significant bands in the seeds that were shade-dried before storage. The result seems to indicate more activity in seeds dried in the shade to water content of $20 \%$ before storage; such seeds had higher germination percentage and vigor.

This result shows the appearance or increase in intensity of bands with increasing water loss by seeds or higher content of heat-resistant proteins. This is indicative that drying induced the synthesis of this protein in seeds dried to low moisture contents. This fact is more clearly observed for the seeds quickly dried before storage and for seeds in both drying methods after storage. 


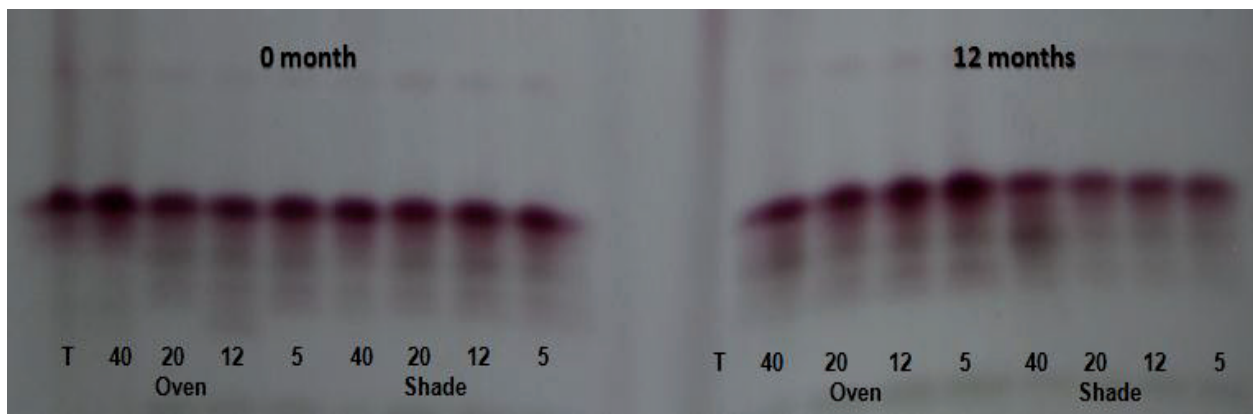

Figure 5. Enzymatic profiles of esterase (EST) on seeds of Coffea arabica L., depending on drying methods, water content (\%) and time of storage.

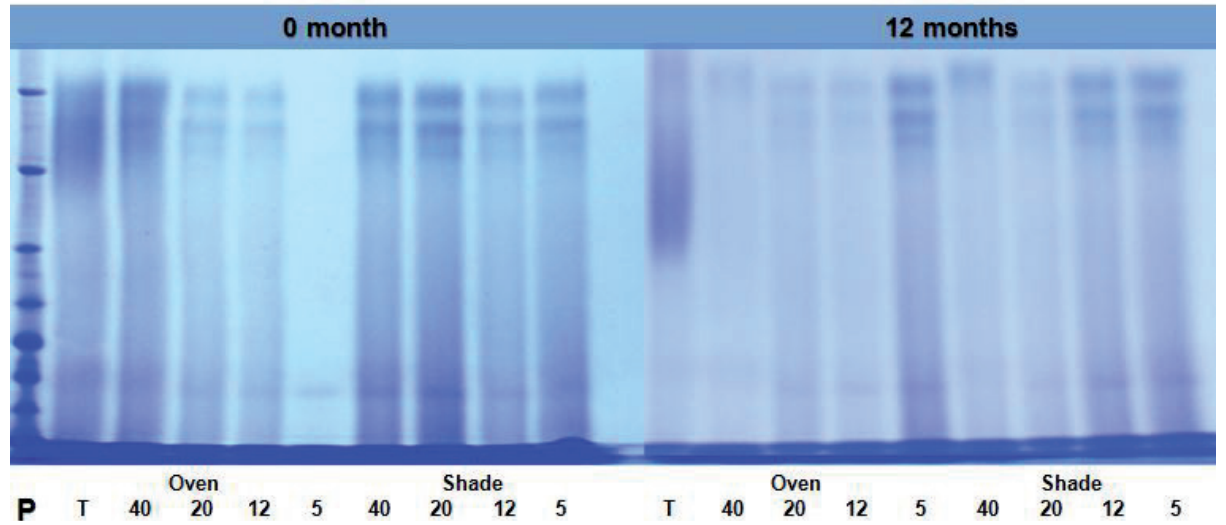

Figure 6. Enzymatic profiles of heat-resistant proteins in seeds of Coffea arabica L., depending on drying methods, water content (\%) and time of storage.

Seeds not subjected to drying showed no bands, which can relate this protein system to desiccation intolerance in these seeds, a fact that was also noted by Guimarães et al. (2002) in coffee seeds. Veiga et al. (2007) did not observe activity of heat resistant proteins in seeds that were not subjected to drying at all storage times evaluated.

These proteins are synthesized and accumulated at the later stages of seed development, before or during drying, and their stability, hydrophilicity and abundance in desiccation resistant organisms suggest a role associated with tolerance to drying because they protect seeds and are very important for preventing drying-induced damage (Vidigal et al., 2009). The drying process in seeds appears to induce the expression of alleles, thereby promoting the onset or exacerbation of bands. These results suggest low tolerance to drying and low longevity of stored coffee seeds, which can be correlated with the results obtained in the physiological tests.

Bands of the peroxidase enzyme tend to increase in intensity (activity) due to a decrease in the water content of the seeds subjected to fast drying (Figure 7). When slow drying in the shade was used, the opposite effect was observed, and the intensity of the bands decreased as seeds lost water. There was also lower activity of bands in seeds dried in the shade compared with seeds dried in the dryer. This was more evident after storage. In moist seeds, that is, those that were not dried (control), the repair mechanisms that include free radical scavenger enzymes such as catalase and peroxidase were not triggered. This was confirmed by the absence of peroxidase activity for seeds not submitted to drying.

For the enzyme system of superoxide dismutase (Figure 8), activity was identified for seeds subjected to the two drying processes; however, no activity was observed for seeds harvested at 52\% moisture (non dried) before and after storage. It should be noted that for seeds dried quickly to water content of $40 \%$, the presence of bands was not identified, either. For seeds dried in the shade to $40 \%$ water content, slow drying may have led to the activation of this enzyme system. According to Berjak (2006), the absence or reduction in the activity of free radical scavenger enzymes increases the sensitivity of the seeds to oxidative stress. 


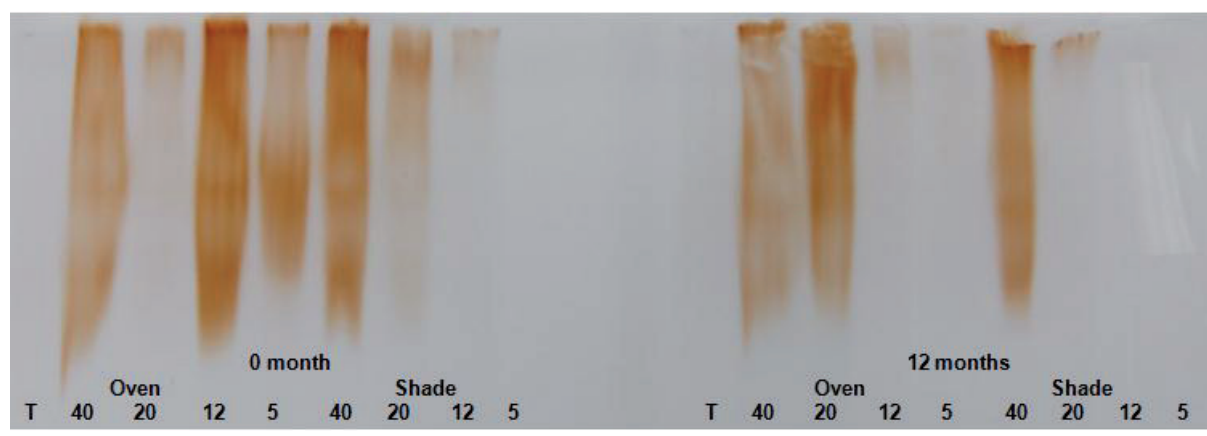

Figure 7. Enzymatic profiles of peroxidase (PO) in seeds of Coffea arabica L., depending on drying methods, water content $(\%)$ and time of storage.

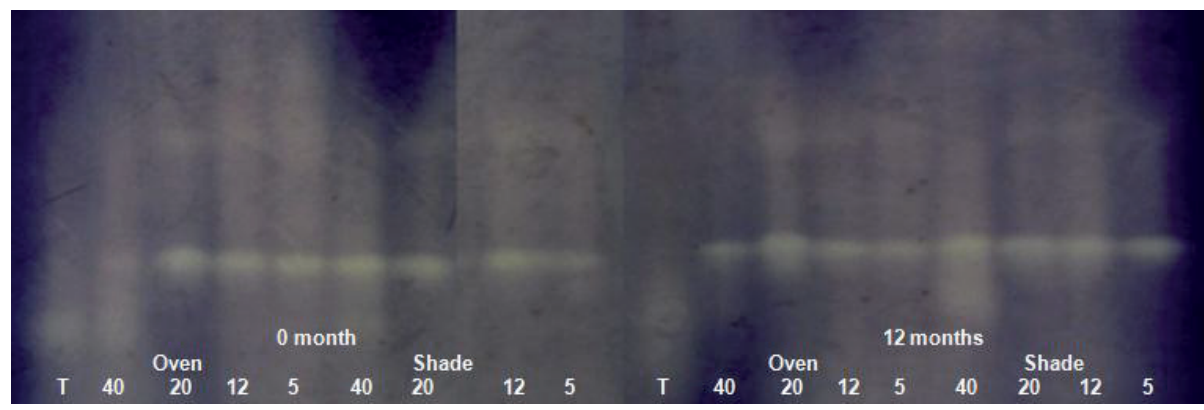

Figure 8. Enzymatic profiles of superoxide dismutase (SOD) in seeds of Coffea arabica L., depending on drying methods, water content $(\%)$ and time of storage.

\section{Conclusions}

Slow shade drying to $20 \%$ water content facilitates the maintenance of quality in coffee seeds for up to twelve months of storage.

\section{Acknowledgements}

The authors are thankful to the Coordination for the Improvement of Higher Education Personnel (CAPES) for granting a postdoctoral scholarship and financial support for the research.

\section{References}

ALFENAS, A. C. Eletroforese e marcadores bioquímicos em plantas $e$ microrganismos. 2.ed. Viçosa: UFV, 2006. 627p.

ARAÚJO, R. F.; ARAUJO, E. F.; CECON, P.R; SOFIATTI, V. Conservação de sementes de café (Coffea arabica L.) despolpado e não despolpado. Revista Brasileira de Sementes, v.30, n.3, p.71-078, 2008. http://www.scielo. $\mathrm{br} / \mathrm{pdf} / \mathrm{rbs} / \mathrm{v} 30 \mathrm{n} 3 / 10 . \mathrm{pdf}$
BAILLY, C.; BOGATEK-LESZCZYNSKA, R.; CÔME, D.; CORBINEAU, F. Changes in activities of antioxidant enzymes and lipoxygenase during growth of sunflower seedlings from seeds of different vigour. Seed Science Research, v.12, n.1, p.47-55, 2002. http://journals.cambridge.org/action/ displayabstract? frompage $=$ online \&aid $=704312$

BERJAK, P. Unifying perspectives of some mechanisms basic to desiccation tolerance across life forms. Seed Science Research, v.16, p.1-15, 2006. $\mathrm{http} / / /$ journals.cambridge.org/action/displayAbstract?fromPage $=$ online $\&$ aid $=705716 \&$ fileId $=$ S0960258506000018

BRANDÃO JR, D. S.; VIEIRA, M. G. G. C.; HILHORST, H. W. M. Aquisição da tolerância à dessecação nos diferentes estádios de desenvolvimento de sementes de cafeeiro (Coffea arabica L.). Ciência e Agrotecnologia, v.26, n.4, p.673-681, 2002. http://www.scielo.br/scielo.php?pid=S0101$31222002000200004 \&$ script $=$ sci $\operatorname{arttext}$

BRASIL. Ministério da Agricultura, Pecuária e Abastecimento. Regras para Análises de Sementes. Ministério da Agricultura, Pecuária e Abastecimento. Secretaria de Defesa Agropecuária. Brasília: MAPA/ACS, 2009. 395p. http:// www.bs.cca.ufsc.br/publicacoes/regras\%20analise\%20sementes.pdf

CARVAlHO, G. R., GUIMARÃES, P. T. G.; NOGUEIRA, A. M.; REZENDE, J. C. Normas e padrões para a comercialização de sementes e mudas de cafeeiros em Minas Gerais. Informe Agropecuário, Belo Horizonte: EPAMIG, v. 29, n. 247, p. 24-30, 2008.

DUSSERT, S.; DAVEY, M.W.; LAFFARGUE, A.; DOUlBEAU,S.; SWENNEN, R,. ETIENNE, H. Oxidative stress, phospholipids loss and lipid hydrolysis during drying and storage of termediate seeds. Physiologia Plantarum, v.127, p.192-204, 2006. http://onlinelibrary.wiley.com/ doi/10.1111/j.1399-3054.2006.00666.x/full 
ELLIS, R. H.; HONG, T. D.; ROBERTS, E. H. An intermediate category of seed storage behavior? II. Effects of provenance, immaturity, and imbibition on desiccation-tolerance in coffee. Journal of Experimental Botany, v.42, n. 238, p. 653-657, 1991. http://jxb.oxfordjournals.org/content/42/5/653

FERREIRA, D. F. Sisvar: a computer statistical analysis system. Revista Ciência e Agrotecnologia, v.35, n.6, p.1039-1042, 2011. http://www. scielo. br/pdf/cagro/v35n6/a01v35n6.pdf

GENTIL, D. F. O. Conservação de sementes do cafeeiro: resultados discordantes ou complementares? Bragantia, v.60, n.3, p.149-154, 2001. http://www.scielo.br/pdf/brag/v60n3/a01v60n3.pdf

GUIMARÃES, R. M.; VIEIRA, M. G. G. C.; FRAGA, A. C.; VON PINHO, E. V .R.; FERRAZ, V.P. Tolerância à dessecação em sementes de cafeeiro (Coffea arabica L.). Ciência e Agrotecnologia, v.26, p.128-139, 2002. http://www. scielo.br/scielo.php?pid=S0101-31222002000200004\&script=sci arttext

NAKADA, P. G.; OLIVEIRA, J. A.; MELO, L. C.; GOMES, L. A. A.; VON PINHO, E. V. R. Desempenho durante o armazenamento de sementes de pepino submetidas a diferentes métodos de secagem. Revista Brasileira de Sementes, v.32, n.3, p.42-051, 2010. http://www.scielo.br/pdf/rbs/v33n1/13.pdf.

ROSA, S.D.V.F.; BRANDÃO JR, D. S.; VON PINHO, E. V. R.; VEIGA, A.D.; CASTRO, L.H. Effects of different drying rates on the physiological quality of Coffea canephora Pierre seeds. Brazilian Journal of Plant Physiology, v.17, n.2, p.199-205, 2005. http://www.scielo.br/scielo. php?script=sci_arttext\&pid=S1677-04202005000200002\&lng=en\&tlng=en. 10.1590/S1677-04202005000200002.

SANTOS, G. C.; VON PINHO, E. V. R.; ROSA, S.D.V.F. Gene expression of coffee seed oxidation and germination processes during drying. Genetics and Molecular Research, v.12, n.4, p.6968-6982, 2013. http://www.funpecrp. com.br/gmr/year2013/vol12-4/pdf/gmr3263.pdf
SANTOS, F. C.; ROSA, S. D. V. F..; VON PINHO, E. V. R.; CIRILLO, M. A.; CLEMENTE, A. C. S. Desiccation sensitivity from different coffee seed phenological stages. Journal of Seed Science, v. 36 , n.1, p. 25-31, 2014. http://www.scielo.br/scielo.php?script=sci arttext\&pid=S2317-15372014000100003\&lng=en\&tlng=en. 10.1590/ S2317-15372014000100003.

TAKAHASHI, A.; OHTANI, N.; HARA, E. Irreversibility of cellular senescence: dual roles of p16INK4a/Rb-pathway in cell cycle control. Cell Division, v.2, n.10, p.1-5, 2007. http://www.celldiv.com/content/2/1/10

VEIGA, A.D.; GUIMARÃES, R.M.; ROSA, S.D.V.F.; VON PINHO, E.V.R.; SILVA, L.H.C.; VEIGA, A.D. Armazenabilidade de sementes de cafeeiro em diferentes estádios de maturação e submetidas a diferentes métodos de secagem. Revista Brasileira de Sementes, v.29, n.1, p.83-91, 2007. http://www. scielo.br/scielo.php?script=sci_arttext\&pid=S0101-31222007000100012

VIDIGAL, D. S.; DIAS, D. C. F. S.; VON PINHO, E. V. R.; DIAS, L. A. S. Alterações fisiológicas e enzimáticas durante a maturação de sementes de pimenta (Capsicum annuum L.). Revista Brasileira de Sementes, v.31, n.2, p.129-136, 2009. http://www.scielo.br/pdf/rbs/v31n2/v31n2a15.pdf

VIEIRA, A. R.; OLIVEIRA, J.A.; GUIMARÃES, R.M.; PEREIRA, C.E.; CARVALHO, F.E. Armazenamento de sementes de cafeeiro: ambientes e métodos de secagem. Revista Brasileira de Sementes, v.29, n.1, p.76-82, 2007. http://www.scielo.br/scielo.php?pid=S0101$31222007000100011 \&$ script $=$ sci_abstract\&tlng=pt 